\title{
Devaluation of Workers' Lives in the Neo-Liberal Order and the Reflections on the
}

\section{Media}

\author{
Mine Karakus Yetkin, Anadolu University, Turkey \\ Filiz Goktuna Yaylaci, Anadolu University, Turkey
}

\begin{abstract}
Within the neo-liberal order, the workers who are only considered as labour power are left to precariousness. Globalization and neo-liberal policies as the reflection of the logic of the contemporary economy-politics are substantial concepts in understanding the minimization of costs of labour and the increase in the worker fatalities on behalf of profit maximization. On 11 March 2012, in a shopping mall construction site called Marmara Park in Istanbul, 11 workers lost their life when their tents caught fire. The tents were shelters for the construction workers who were employed by a subcontractor and the heating stove was the cause of the fire. After Public Prosecutor of Bakırköy's investigation and the lawsuit, the court decided the 11 workers who lost their lives to be faulty. The fact that tents were given to workers for their stay at the construction site indicates that they are migrant workers who were dependent subjects to exploitation and to adverse working conditions, which are clearly the implications of neo-liberal economy policies. This study analyses how the fire on 11 March 2012 that claimed 11 workers' lives and defined as "workplace accident" by the hegemonic discourse is reflected on the Turkish media, within the framework of theoretical discussions on neoliberalism, subcontracting and deregulation of labour. For that purpose, content and discourse analysis are conducted on the news published in the Turkish printed press. The data are collected through PRNet data base program as well as research engines of the online newspapers. From the preliminary findings, it can be suggested that, when the gravity of the incident is considered the space given to the fire and the tragedy in the media was not significant. Furthermore, the newspapers constructed their news about the fire in accordance with their political standing.
\end{abstract}

Keywords: Printed Press, Neo-liberalism, workplace disasters, perception management, subcontacting 


\section{Introduction}

In the presented study, the fire occurred on 11 March 2012 and took 11 workers' lives, that is considered as work place accident by the hegemonic discourse is analysed as reflected on the media. In discussing the fatal workplace accidents that has been tremendously increasing for the past decade it should be acknowledged that such incidencts were "resulted in death and injury even though preventive accidents, precautions were not taken with the pursue of profit maximization" (Taşbaşı et.al, 2014). The workplace accidents that are increasingly continuing and turning into work murders attract the public attention only when more than tens of workers die. The reason behind normalization of the fatal accidents takes its root from the hegemonic concepts of "natality", "accident" and "fate". In a way consent of the workers to the deadly conditions and eventually murderous accidents is constructed by the hegemony with conservative and religious understandings of fate. Furthermore it is possible to mention that, as a result of the imposition of neo-liberal policies, workers instead of the employer and owner of the capital pay the cost of the deadly accidents. In analyzing the workplace accidents as implications of the hegemonic neoliberal policies in the developing world as well as in Turkey, it is important to elaborate how the situation is reflected on the media and how it is interrelated with hegemonic discourse.

Within the neo-liberal order, the workers who are only considered as labour power are left to precariousness. Globalization and neo-liberal policies as the reflection of the logic of the contemporary economy-politics are substantial concepts in understanding the minimization of costs of labour and the increase in the worker mortalities on behalf of profit maximization especially in the developing and undeveloped world. Within this framework the present paper analyzes the dimensions of devaluation of labor and insecurity at the work place of construction sector. For that purpose, the study focuses on the fire occurred on 11 March 2012, in a shopping mall construction site, the reasons and aftermath as reflected on the media. Fire occurred from electric heating stove at the tents that are used as dorms for workers in a construction site of a shopping mall called Marmara Park in Istanbul and 11 workers lost their life. The tents were shelters -improperly equipped with unsuitable material for winter conditions- for the construction workers who were employed by a subcontractor. After Public Prosecutor of Bakırköy's investigation and the lawsuit, the court decided the 11 workers who lost their lives to be at fault. The fact that tents were given to workers for their stay at the construction site indicates that they are migrant workers who were dependent 
subjects to exploitation and to adverse working conditions, which are clearly the implications of neo-liberal economy policies. This study analyses how the fire on 11 March 2012 that claimed 11 workers' lives and defined as 'workplace accident" by the hegemonic discourse is reflected on the Turkish media, within the framework of theoretical discussions on neoliberalism, subcontracting and deregulation of labour. Understanding globalization and neoliberal policies as the economy-policy logic behind globalization is crucial in elaborating the background of increasing mortality rate in workplace, which is a consequence of minimization of labor costs in behalf of profit maximization.

The study bases its analysis on two main discussions. As for understanding the background and logic of the working conditions in general and the subject matter in particular, theoretical discussions on neo-liberal politics, its implications on Turkey and economic transformations are elaborated. In understanding how devaluation of labor and unsafe working conditions of workers are reflected on the media the authors refer to the notion of perception management.

\section{Neo-liberal Order and Transformation of Labor}

In order to understand the economic restructuration process followed by social transformations it is important to elaborate the impact of neoliberal ideology in general. Neoliberal ideology since the last quarter of $20^{\text {th }} \mathrm{c}$. has been highly effective in the development of consumption society, economic boom based on service sector, destruction of traditional solidarity networks by the values of individualism (Insel, 2011: 11). The social implication of this transformation appears as insecurity and devaluation of labor.

For defining neoliberalism it should be noted that in Harvey's words, "it (neoliberalism) is in the first instance a theory of political economic practices" (2005: 2). The ideology assumes that, liberation of individual entrepreneurship, strong private property rights, free market facilitates advanced human well-being (Harvey, 2005:2). According to the neoliberal ideology as Harvey puts it (2005), the role of the state is just to provide security for and guarantee by force the functioning of the free market with "military", "defence", "police" and "legal structures". The role of the state has come down to guarantor of the proper market functioning devoid of its regulatory and interventionist function (Harvey, 2005:2). 
Following the deep world crisis of the 1970s, neoliberal globalization introduced as the solution to the crisis of capitalism in the 1980s marked the end of Keynesian labour friendly regime. In the developing and undeveloped world, the countries' role became to be the suppliers of labor, raw material and land in the global commodity chain in a political environment where competition and privatization are regarded as primary virtue (Mezzadri, 2009: 128). Privatization, deregulation and competition are considered to improve quality, productivity and efficiency and reduce costs. The neoliberal state by restructuration and new arrangements, introduce market friendly regulations in order to improve its competitiveness in the global market (Harvey, 2005: 65). Within this logic, cheap labor became the main means of competition in the developing world. The cheapness is achieved by segmentation of labour markets, deregulation and erosion of social security provisions.

The adverse effects of the globalization of capital and neoliberalism can be two-fold. To begin with, in order to attract the highly mobile capital, the governments deregulate the national markets in favor of the foreign investors. This implies that, they divert from the Keynesian welfare state in order to provide suitable conditions of cheap labor and land. Additionally, they release the burden of tax as a main source of social welfare provisionsfrom the investments.

Secondly, the global capitalism with free market economy is exacerbating the core-periphery dichotomy. That's to say; there are developed states from which the strong global corporations controlling the global trade and finance have flourished. Even though these corporations transgressed the national borders, the headquarters and the main executive units remain in the states where the human capital is highly valued and expensive. On the other hand, with the pursuit of high profits, the corporations, which control the global capital flow, move overseas with the surge of cheap labor and lands in a sense creating a new system of global imperialism with a different way of exploitation. In order to better illustrate the situation Appadurai points to the same fact by stating that " $(G)$ lobalization is demonstrably creating increased inequalities both within and across societies, spiraling (...) unavailable relations between finance and manufacturing capital, as well as between goods and the wealth required to purchase them"(Appadurai, 2001: 17). Similarly, in discussing the conditions of Delhi garment industry workers, Mezzandri (2009: 129-133) argues that, the neoliberal understanding of labour manifested itself in developed and developing countries differently as 
manufacturing has moved to poorer economies punished the "troublesome northern labor". Whereas in the developing world, deterioration of labor conditions in favour of capital was imposed as a "pre-condition for economic growth". Cheap labor and excessive unqualified cheap labor force are imposed to be advantages of these countries.

Baumann (1999) defines this process as a "new form of worldwide stratification", a new "socio-cultural hierarchy is generated". At the same time Baumann asserts that, homogenization and fragmentation, globalisation and localization are parallel processes that are triggered by the fundamental changes in the field of hi-tech industry. In this globalization process, "privileges" and "deprivation", "wealth" and "poverty", "resources" and "weaknesses", "power" and "powerlessness", "freedom" and "limitations" are being redistributed. Baumann defines this process in which the minority holds all the wealth while the majority is struggling deprivation as the global factors for the localization of poverty. The representation of wealth and poverty in the media is also the reflection of the dichotomy as the global is represented with the wealth it brings to the people whilst poverty is being presented as the sui generis choices of the Third World populations. In summary, the mobile global capital brings up-rootedness, insecure jobs, sub-human working and living conditions and economic dependency to the developing and undeveloped world.

What follows from this argument is that, the operations of the neo-liberal economic system magnify the ever-existed discrepancies. The periphery countries become depended on the free market economy and issue their policies on behalf of the interests of the global market owners; sacrificing the wellbeing of their own populations. Secondly, those states, which become the center of gravity of the international finance and attract foreign investors become more prosperous compared to their counterparts that fail to do so. Even the prosperity is ephemeral and artificial since whenever the foreign investors are discontent with the changing situation in those countries, they take all their financial resources and move away for new destinations, leaving the country deserted.

At this point, it may be useful to refer to John Keane (2003) for supporting the argument. He conceptualizes the new phase of neo-liberal understanding of the global economy as turbocapitalism. He defines turbocapitalism as "a species of private enterprise driven by the desire for emancipation from social custom, territorial state interference, taxation restrictions, 
trade union intransigence and all other external restrictions upon the free movement of capital in search of profit." For better illustrating the concept, J. Keane (2003: 67-68) compares with its ascendent era of Keynesian welfare state by stating that 'markets were embedded in webs of government' and 'private investment was subject to various governmental restrictions'. However in the second phase '(M)arkets become disembedded: they riggle out of social obligations and break free of territorrially based government controls.' (Keane, 2003: 67$68)$.

The states were the fertile soil to nurture the corporations with their protectionist and regulatory mechanisms when they were at the stage of infant industry. In time, some become the world giant firms and institutions; progressing above and beyond the nation states, the states then start to compete with each other to attract investments in the cost of the welfare of their own citizens. In other words, states become the guarantors for the sustainability of the neo-liberal global system by providing cheap labour, an appropriate market for the consumption of the imported goods and restrictive measures for the opposition groups (Ishay, 2004: 183). In fact the existence of such structures can be considered as the spatial reflections of the underlying logic of neo-liberalist operations whereby all values and moral related to work and human labor are challenged by the desire for profit maximization and legitimized as the freedom of private venture. The actors of this system that force workers to sub-human conditions for limiting the labor costs, threaten governments by withdrawing their investments in any case of social dissent (Klein, 2002).

The above mentioned operation of global commodity chains liberate transnational corporations from the governance of labour. In Mezzandri's words, "through global outsourcing, TNCs were able to cut labour costs and the costs of risks and investment" (Mezzadri, 2009: 129). As in the case of the garment industry in Delhi, "the labourforce employed are migratory and are rarely directly employed by the garment producers. Generally, they are managed by labour contractors ... In this way, the management of labour becomes disarticulated from that of production. Exporters are lightened of the labour burden, which instead is managed by the labour contractor." (Mezzadri, 2009: 133).

Klein (2002) in successfully elaborating the conditions of production and manufacture in the developing third world countries, briefly state that, the marketing geniuses generate a system 
of production by creating a laborforce army compsed of unattached workers to liberate the capital from "labor burden". When she examines the worker profiles the process crystalizes as the workers are generally unmarried daughters of farmer families from distant regions. As the families loose their lands to free trade regions and tourism send their daughters to distant industrial regions as workers. The daughters away from family and dislocated try to survive in the grip of adverse sheltering condition, malnutrition, poverty, homelessness, sleep deprivation and homesickness.

In this neoliberal order of exploitation the multinational companies not only confine the Third World popuations into deprivation and inhumane conditions for the sake of cheap labor but also in order to control and reproduce the mechanisms of exploitation, shape and influence the social policies of these countries. For instance in Endonesia the Nike-Reebok subcontractors declared that the increase in legal minimum wages would take that country out of the market; the representatives of Nike-Reebok-Adidas subcontractors' call for the army to repress workers' strike; the repressive practices and human rights violation of the military dictatorship in Nigeria that protect the interests of Shell are all instances neoliberal capitalism's social and economic implications on the Third World population (Werner \& Weiss, 2003: 98-110; Klein, 2002: 405-407).

For final remarks, the globalization of capital the closed domestic economies are forced to open to global markets and a global system of economy emerged. A slight crisis in any capitalist country adversely affects the rest of the world. The toll of this process is on the undeveloped and developing countries. These countries with frequent crises have unsteady and dependend economy that bring more informalization, unemployment, poverty, subalternety and deepening of income gaps.

\section{Methodology}

On 11 March 2012, at the construction site of Esenyurt Marmara Park Shopping Mall, three tents used for the accomodation of the workers caught fire and 11 workers lost their life. In this paper it is attempted to elaborate how the tragic incident was reflected on the media and understand how perception management was realized through media on this particular accident. For that purpose in this study, the researchers tried to reach all news content on the printed media and on the internet. Within this context, PRNet database program was used for 
data searching of the printed media during the four years period -to include the trial processbetween 2012-2015. The TV news videos and videos presenting the statements of lawyers and family members were reached through online search engines. The researchers use the keywords "death of 11 workers" "tent fire in Esenyurt", "11 workers died" "Marmara Park Shopping Mall". With content and discourse analysis, the researchers tried to map out the dimensions of perception management exercised by the media based on the news on the tragic incident.

The study take its first steps from the case study on the work place fire took 11 lives. The researchers get the first information of the incident from the media and as the course of the events was followed it was realized that the tragedy did not take the space it deserved on the mass media. Unfortunately, fatal workplace accidents continue in an ascending pace and the fire is not a unique incident of fatal accidents, so the researchers were compelled to investigate deeper.

As the research continued the main question mark was; why some newspapers gave 17 news and some with highest circulation rates give limited space and even no space at all? Furthermore, the incident described as workplace accident, if the necessary precautions were taken would 11 workers loose their lives? While questioning the issue, the researchers found themselves in the discussions on neoliberal politics. Consequently a three-tier research was conducted, one is neoliberal policy, second one is the case study and the third one is the media and perception management, which are strictly linked to each other.

Only the newspapers that are printed and scanned by PRNet are analysed. For instance Milliyet newspaper published 18 news online when searched with the keywords " 11 workers died". However, the researchers only included PRnet data on their analysis so online news are excluded from research. For better elaborating the Fire and to follow up the incident, the videos broadcasted on tv and social media are reached through online search engines and analysed. The researchers reached 81 videos 54 of them are about the news presented on mainstream national broadcasts. The rest of the videos are published on the alternative media presenting the declerations of the lawyers and families of the deceased during the trials. 


\section{Analysis and Discussions: Neoliberal Transformation of Labor and Implications for} Turkey

The course of the discussion within the light of the data analysis will be as following, first of all a brief information on the process of neoliberal transformation of Turkey will be given. The tent fire and the death of 11 workers is among the increasing volume of fatal workplace accidents which is an implication of neoliberal policies towards limiting labour costs. Therefore the second part of the discussion is on the devaluation of labour and its significance on the occurance of tent fire. Thirdly, discussion on the role of subcontraction since, subcontraction is introduced as a strategy for the capitalists to emancipate themselves from the responsibilities of the labor. As seen in the case of the tent fire, the subcontracting firm carry all the responsibility of the costs and after the fire the accident. Fourthly, since the deceased workers were predominantly migrant workers who left their hometowns in search for employment and only found jobs offering conditions under subsistence level the discussion will continue with brief information of agricultural transformation and lack of employment opportunities. Finally for elaborating the perception management exercised by the media, how the news presented at the course of the incident and the following trials will be analysed.

\section{Neoliberal Transformation}

Prevalent since 1970s, the neoliberal policies gained a hegemonic standing by the 1980s throughout the world and Turkey, 24 January 1980 programme introduced a market oriented restructuration of the economy and export oriented industrialization policies. Followed by 12 September 1980 military coup d'etat, silenced all social oppositions in addition to the introduction of a conservative and oppressive 1980 Constitution. Therefore the economic as well as institutional/legal and social foundations of neoliberal strategy has been constructed (Mütevellioğlu \& Işık, 2009: 159-160).

For understanding the factors and underlying dynamics of increase in fatal workplace accidents in general and the tent fire on 11.03.2012 in particular, the response of the Turkish government and state with its legislative, administrative and institutional mechanisms to the pressure of global competition and capitalists cannot be cast aside. The neoliberal transformation of Turkish economic and social structures gained impetus since the beginnings of 2000s. An aggresive privatization program, concessions to foreign capital, legislation 
enabling deregularization of labor and answering the demands of business are among the measures taken by the government for opening the country to neoliberal order (Öztürk, 2015:135). Bedirhanoğlu and Yalman mention (2009:120-121), economy policy implemented since 2000s carry the features of jobless growth, where economic growth and increase in productivity are not reflected on real wages and employment rates. Strictly speaking, the entire population have not benefited the economic prosperity.

In Turkey this process of neoliberalization generated itself with increasing poverty as the wealthy prospere. As Erbaş states (2009:61), the deterioration of worker conditions, the market became the only authority, increase submission in the work and social relations and strengthen protectionism. To give brief information on the neoliberal transformation process in Turkey, the role of the authoritarian state is detrimental. Harvey (2005:7), calls the "state apparatus whose fundamental mission was to facilitate conditions for profitable capital accumulation on the part of both domestic and foreign capital" as neoliberal state.

The factors that caused the tent fire on 11.03.2012, the terms and conditions of employment of the deceased workers, their despair and lack of alternatives for finding jobs meeting the basic standarts of humane conditions, the judicial process protecting the main employers and capitalists are not unique cases of manifestations of the above mentioned neoliberal features in Turkey.

\section{Devaluation of Labor}

For discussing the implication of neo-liberal restructuration on labor and workers, Polanyi in his study of "Great Transformation" refers to commodification of labor. Social dynamics and social interventions to the market have limited the boundaries of commodification of labor up until the last two decades of the $20^{\text {th }}$ century (Polanyi, 2000; Mütevellioğlu \& Iş1k, 2009: 163). However in the last quarter of the $20^{\text {th }}$ century, the rules limiting the commodification of labor has been dissolved by the neoliberal policies. As it is being observed in the deteroiarating working conditions as the work hours has been increased under the name of flexibility, social security rights are becoming highly limited, the rapid increase in the fatal workplace accidents, increase in occupational and work place related diseases, increase in poverty, unemployment are all the implications of erosion of these rules and deepening of market dependence of labor (Mütevellioğlu \& Işık 2009: 163). The neoliberal policies, 
enabled employers to adopt exploitative practices such as, "longer working hours without pay, delays in the payment of wages, offers to give holidays earlier than usual, forced retirement and resignation followed by delays in severance pay became a common practice among employeres" (Hoşgör, 2015:216). Therefore, the benefits of the neoliberal transformation to the capitalists and to the hegemonic political powers rather deteriorated the welfare of the people, put constraints on employment and deepened poverty, putting the costs of neoliberal transformation onto the society (Hoşgör, 2015:216). For instance as an answer to the employers' and capitalists' pressures and taking into account World Bank's assumption that the reason for unemployment is the strong regulations on flexible labor, in 2003 Turkish government issued 4857 number Labor Code introduced new regulations increasing the flexibility of work life. The new law enabled the flexibility of working hours, flexibility of wages, inter-company flexibility, on-call employment, temporary relocation of workers, unpaid overtime work (Mütevellioğlu \& Işık, 2009: 183-184; Ekmekçioğlu, 2003: 74-77). It is impossible for a political approach that regard labor protective measurements as burden and leaving workers in detrimental conditions under the name of "modern forms of employment" be consistent with social justice (Ekmekçioğlu, 2003: 74). One of the results of this regulation is the widespreading practices of outsourcing and subcontracting. Both in public and private sectors, this practice involves excluding the labor and work process from the enterprise. Therefore the workers and their work are not binding the main employer but small subemployers making contracts with the main employer. Which eliminates the 'burden' of labor and social welfare provisions from the main employers. The subcontracting firms mostly of small sized enterprises are more capable of escaping the legal enforcements employing workers without insurance with lower wages and longer working hours. Furthermore, according to the demands of the main employer these small sized enterprises can easily lay off workers.

The most devastating impact of these policies on the labor is the increasing number of death and fatal injuries at the labor intensive sectors such as construction, mining and shipyards and manufacture. In 2013 at least 1235 workers have lost their lives due to murder like accidents at the worplace and the number increased to 1703 in 2015. The emphasis on the notion of "at least" is important because the numbers are only those which reflected are on the media, and the media tend to give the minimum numbers (İş Cinayetleri Almanağı 2015, 2016). What is striking that the deaths due to workplace conditions take very limited place on the media and 
from this limited space the numbers are over thousands per year. All our discussions based on the data and events that are reflected and eventually make known to the public by the media. Unfortunately it is acknowledged that, numerous fatal accidents are not even recorded and taken to the press therefore these are the only limited numbers. Every ten minutes one worker dies in the constructions as ILO Turkish Representative states "at the construction sector, in the world every year 60.000 deadly accidents occur and in every 10 minutes one person dies at the construction". Malatya Kent newspaper on 19.03.2012 "We are the First at the Workplace Accidents in EU”, Ortadoğu Newspaper 19.03.2012 “One person dies every 10 minutes in Construction", Yeni Çağ 19.03.2012 "What is the Importance of Life!" "When It comes to Accidents No one Can Take Over Us", Zaman 19.03.2012 "Work Health and Security as a Human and Believer Right", 18.03.2012 Birgün "We are the First in Europe and Third in the World in Workplace Accidents", 18.03.2012 Güneş "This Leadership is Shameful: Humiliating Record". Six newspaper with the above mentioned titles reports the numbers declared by ILO about workplace accidents and state of Turkey in the data. According to the numbers declared by the Chamber of Architects, beyond the incidents reflected on the media, in the last decade the number of workers lost their lives during workplace accidents is above 10.000. According to Chamber and ILO in Turkey especially at the metropolitan constructions either workers' safety and insecurity at the surroundings of the construction sites are non-discardable. Furthermore, because of the enformal and undocumented employment, the undocumented work accidents the number of deaths are impossible to estimate. In the case of the eleven workers, two workers' social security record was issued on-line right after the fire occurred; Çetin Coşkun at 22:43 and Sevdin Özen at 22:51 also verified by head of Social Security Institution. From their families statements it is found out that the two workers have been working undocumented and withouth insurance for three. This was also mentioned in the following newspapers İstanbul Yeni Nesil on 15.03.2012 "They are Insured after their death", Ortadoğu 15.03.2012 "Social Security Institution Verified”, Özgür Gündem on 15.03.2012 "Insurance Officially Verified the Scam”, Radikal on 15.03.2012 "Insurance after Death, the penalty for insurance after death is 1.402 TL", Taraf on 15.03.2012 "Bitter Confessions", Türkiye on 15.03.2015 "Social Security Institution Verified Insurance after Death", Bursa Kent on 14.03.2012 "Now Insurance Scam”, Eskişehir Sakarya on 14.03.2012 "Workers were Insured after They are Burned", Vatan, 14.03.2012 "They Made Insurance at the Night of the Fire". 
The high rates of worker mortality, long work hours, deregulation are all manifestations of the assertive neoliberal policies. As a result of the neo-liberal policies of post 1980s, the wrokers empoverished, became invisible and the concern of unemployment at the cost of their lives workers forcefully consent to the demands and requirements of the employers. For instance, in Aydınlık newspaper on 17.03.2012 it is mentioned that "There are Workers still staying in tents: No lessons are taken from the 11 deaths", "Survivors of the fire, Recep Özçelik interviewed by Aydınlık mention that he is newly employed in another construction site 'They said that we will be staying in tents at the new job, and I immediately choose the window side. At least in case of fire I will have the chance to escape." The fact that the fire survivor finding another job as construction worker subject to similar detrimental conditions presents the dimensions of forced consent of the workers.

Quoting from one of the survivors "I had been working there for 11 days. The conditions were awful, the accommodation facilities where we slept, the base was muddy, the electric wires had electrical leakage, when we complained they said 'you are workers, you'll live in this conditions, if you don't like you are free to go" "from the $8^{\text {th }}$ Consciousness and Justice Watch (https://www.youtube.com/watch?v=MdLQzE1MN5A, accessed on 18.05.2016). The wife of one of the deceased workers reveal the dimensions of devaluation of workers in the eyes of the employers when she stated on a reality show broadcasted on Kanal Türk that the lawyers of the company called her and offered 40.000 Turkish Liras and not go to court in return. The lost of a husband and father for a family can be exchanged with money and with 40.000 Turkish Liras in the eyes of the employers (https://www.youtube.com/watch?v=GtP6K0dmTaw, accessed on 02.05.2016).

\section{Agricultural Transformation and Migrant Workers}

In Turkey, population increase and rural to urban migration are the main demographic factors shaping the labor market. The industrial employment always remained under 20\%, employment to large extent concentrate in the small sized enterprises labor force is predominantly of medium level educated and unqualified, the state and union supervision is weak, fragmented and uninstitutionalised labor market Turkey represents the features of undeveloped capitalism (Mütevellioğlu\& Iş1k, 2009: 166). 
Starting from the 1980s Turkey pursued a policy for limiting and eventually abolishing all agricultural subsidies. As started in IMF supported 5 April 1994 decisions, and responding the pressures of IMF and World Bank for the erosion of agricultural production finally in 2000 Turkey promised IMF and World Bank to give an end to agricultural subsidies. The reflections of the agricultural policies are devastating for a predominantly rural society, agricultural workers, loosing their income earning activities as a result of the policies are rapidly impoverished also increased the volume of rural to urban migration. However the state policies of jobless growth, deindustrialization resulted in the newly arriving crowds to fill in the ranks of temporary, undocumented and precarious jobs. Therefore the erosion of agricultural production resulted in the transformation of poverty from rural to urban aresas, the former agricultural workers now employed in the irregular, undocumented sector, work for long term withouth any insurance. The new migrants are faced and forced into harsher conditions of living and working (Mütevellioğlu \& Işık, 2009: 173). As observed in the case of the construction workers in the Marmara Park Shopping Mall, temporariness of dislocated workers are open to all kinds of exploitation. In parallel to Gürsoy (2010) discussions on agricultural seasonal workers within the perspective of neo-liberalism, the workers of the construction sector can be considered as unfree labour. The fact that construction workers as in the case of March 2012 incident, submit to the subhuman conditions of work and forced into life threatening conditions can be regarded as unfree labour. Sassen, when analysing globalization claim that exploitation, dependence and adverse work conditions increases with migration. On the one hand with migration individuals can find jobs but on the other hand, the state of migration create consent and acceptance to the insecure living conditions and alienation (Gürsoy, 2010: 44). Similar to Gürsoy's description of seasonal agricultural workers, the construction workers with Acceptance, take the risk of life threatening conditions. Therefore the thesis of capitalism on emancipation of labor is questionable as in Brass's words, "In developed and underdeveloped countries alike, neo-liberal economic growth is increasingly dependent on insecure, temporary and low-paid employment. Such laissez faire capitalism demonstrates additionally that - contrary to earlier views about the capitalism/unfreedom link - bonded labour is not an obstacle to accumulation, since the free market currently thrives on an unfree workforce." (Brass, 2015: 532). Therefore, it could be talked about free market of unfree labor, that signifies the existence of workers bonded with contracts who do not have the means to sell their own labor. 


\section{Subcontraction}

The Keynesian understanding regarded workers as consumers as well as labourers, concomitantly, the corporations prioritized all sorts of employee rights. In the process of neoliberalism, the introduction of outsourcing and sub-contructor, facilitates in the structural transformation and devaluation of labor. As the multinational corporations exploit the subcontractor, the subcontractor exploits the workers whose wage and conditions are deteriorated in each stage of the operation (Klein, 2002: 233).

Bilgin, Yazıc1, Tutar, Güler and Bilgin in 2015 in collaboration with workers union Hak-İş conducted a survey with 5250 subcontructed workers from 25 different provinces of Turkey. In the Subcontructed Workers' Facts Research Report's Discussion and Evaluation section, it is stated that the subcontracted workers themselves define the reasons for the subcontractor practices as cheap labor, labor devoid of union rights. According to the survey, the most significant problems of subcontractor and outsourced workers are, being transformed into permenant staff cadres, work and wage security and cadre position. Concomitantly, the most ephemeral problem as stated by the workers is the workplace health and security that encompasses their working conditions. The workers state that, the employers consider the expenditure on measure increasing workplaces health and security as burdens. Therefore, as mentioned by workers in the survey employers, make the workers work in an unhealthy envirponment and put the workers in an open risk situation (Bilgin et al, 2015: 109-110). Acar (2010, 164), gives a striking example to the extents of the diminishing of social rights of subcontracted workers in health sector. The subcontracted workers have to pay more money for lunch then the permanent staff at the same hospital, they are not allowed to daycare and shuttle buses, when it comes to rights the suncontracted workers become invisible. In terms of work hours, additional provisions, the subcontracted workers are not given equal rights with cadre staff. For instance cadre staff work for 40 hours a week whereas subcontracted work for 45 hours at the same workplace (Acar, 2010: 172-173). Acar finalizes his discussion on the conditions of workers in health sector by presenting the fact that, the subcontracting firm does not keep any files of their workers, does not provide any health scan and/or preventive vaccination given the fact that the workers encounter all kinds of diseases and medical disposals in the workplace. The subcontracting firm and its subcontractor hospital management are not concerned with the well being of the workers and providing them with healthy working environement as they are concerned with the economic well being and profit 
that the hospital would make (Acar, 2010: 174). As for the case study on the 11 March 2012 fire, the workers were employed by subcontractor firm KALDEM that took the labor burden from the German main employer firm ECE Group. On 10 July 2015, the partners of subcontractor KALDEM construction and the electrician condemned to 10 years of prison, the workplace safety and health specialist employees condemned to 5 years of prison. The court decision can be suggested as a significant example of how the process of subcontracting takes the burden from the capital since the main responsibles as the owners of the capital and the state auditors as reinforcers have escaped the punishment and responsibility with the court decisions.

\section{Perception Management and Analysis of the News}

For understanding and explaining the construction of news on the tent fire on 11.03.2012, it is important to base the analysis on the notion of perception management. Perception is a process in which images related to world are shaped through obtaining sensory data and their analysis (Callamari ve Reveron, 2003: 2). Perception involves interpretation accordingly, objectivity and the existence of one reality disappears and subjectivity gains dominance (Saydam, 2012: 88-89). As the marketing and advertisement campaigns' impacts on consumer preferences reveal, perceptions can be managed (Callamari ve Reveron, 2003: 2). The manipulative feature of perception processes introduced the idea of management of perception. Perception management is then, a management technique that is defined as the control and development of the information flow in order to obtain less ambiguous information (Özer, 2012: 148).

The notion of perception management was used and introduced by US military resources. Perception management can be defined as: conveying or blocking the information to the people in order to influence their emotions, instincts and reasonings. The main objective of perception management is to affect the leaders via predictions and shape their behaviors towards the aims. Perception management is composed of integration of certain elements such as reflection of the facts, concealing or distortion of the truth, management of psychological operations (Saydam, 2012: 78-79; The US Department of Defense, 2003; Özer, 2012: 163). However perception management should not be confused with propaganda (Martemucci, 2007: 7). In a broader sense perception management renders a way of presentation of message that would shape target group's viewpoint as desired by the source of the message (Dearth, 
2002: 1; Garfield, 2002). Perception management has two main elements; deception and verification projection and encompass all the activities for influencing the target groups (Özer, 2012: 162).

With reference to Althusser, hegemonic classes have to reproduce politically and ideologically to continue their existence (Koç, 2012: 201). A systematical propaganda is needed in a world in which wealth is accumulated by the few with conflicting interests (Herman \& Chomsky, 1998: 21). As Erdogan highlights (2005: 247) the media products with its content facilitate the reproduction of ideology and conscience (aktaran Koç, 2012: 201). Modern politics is characterized by mass media that accomplishes manifestation of public opinion of all people (van Zoonen, 1998; Yetkin, 2011: 35). With this regard, the hegemonic and political powers produce the dominand discourse through media. The strategies for shaping opinions towards the intersts of others predominantly involve at the conscious leveland depend on manipulation and persuasion (van Dijk, 1993). For instance the statements of Minister of Labor of Turkey of legitimizing the low level of minimum wages, puts the risk of exclusion from global competition and unemployment as the main reason. With his own words "If we increase the minimum wages -which is barely enough for minimum standards of survival- the competitiveness of Turkey will decrease and that would increase unemployment" (March 2013, Haber Türk, accessed on 06.05.2016). These statements on a widely watched TV channel are a significant example of consent production and reproduction of hegemonic discourse. The emphasis on the risk of unemployment, and stating the government as if it is acting on behalf of labor, creates a public opinion of consent to the limited standards by presenting a higher risk. This is highly significant in the case of the workplace accidents; the workers are left no choice but to accept the dangerous conditions. Rather then bettering the circumstances the employers take a manner of "take it or leave it" making workers believe that the better conditions mean unemployment.

\section{News Analysis and Perception Management}

The number of news directly and indirectly mentioning the accident that are printed at the Front page of the news papers is 30. The newspapers are, Sol Newspaper, Günlük Evrensel, Haber Türk, Yurt, İstanbul Son Saat, İstanbul Haberdar, İstanbul Yeni Nesil, Ortadoğu, Vatan, Yeni Şafak, Birgün, Bursa Hakimiyet, Bursa Kent, Milat, Güneş, Ankara Gündem, Yeni Mesaj, Milli Gazete, Taraf, Yeni Asya, Önce Vatan, Gün boyu, Yeni Çağ, Özgür 
Gündem, Yeni Akit, Cumhuriyet, Akşam, Radikal, Takvim, Bizim Gazete. In addition to the numbers presented on the table 1 newspaper published 2 news and 50 newspapers and 3 journals (Yürüyüş, Varlık, Yangın ve Güvenlik Dergi) only 1 news.

Table 1: The number of news as published on the newspapers and the circulation rates

\begin{tabular}{|l|l|l|}
\hline Newspaper & $\begin{array}{l}\text { Circulation } \\
\text { Rate }\end{array}$ & $\begin{array}{l}\text { Number of } \\
\text { News }\end{array}$ \\
\hline $\begin{array}{l}\text { Özgür } \\
\text { Gündem }\end{array}$ & 6919 & 17 \\
\hline Birgün & 20.310 & 14 \\
\hline $\begin{array}{l}\text { Günlük } \\
\text { Evrensel }\end{array}$ & 13.685 & 12 \\
\hline Cumhuriyet & 51.695 & 9 \\
\hline Sol Gazete & 28.735 & 7 \\
\hline Hürriyet & 341.805 & 5 \\
\hline Vatan & 102.743 & 5 \\
\hline Aydınlı & 50.773 & 5 \\
\hline Radikal & 40.370 & 5 \\
\hline Milli Gazete & 30.909 & 5 \\
\hline Orta Doğu & 5.138 & 4 \\
\hline Zaman & 3452 & 3 \\
\hline Hürses & 1176 & 3 \\
\hline Bizim Gazete & 14.000 & 3 \\
\hline HaberTürk & 220.563 & \\
\hline
\end{tabular}

In quick analysis, the news can be grouped under three main subjects. In the first group the newspapers give news directly pointing to the main responsibles and openly addressing the main reasons of the fire. For instance, Birgün 24.11.2012 "It is not Accident, Fate, It is Workplace Murder"; Günlük Evrensel 19.10.2012 "Workers' Tents are Still Burning”, Günlük Evrensel 18.10.2012 “That Building Stands on Blood, Sweat and Tears”, Milli Gazete 16.04.2012 "Work Accidents or Murders", Yeni Akit 16.03.2012 "The Accident Will Not be 
Concealed", Cumhuriyet 15.03.2012 "Social Security is Partner to the Scam", Cumhuriyet 14.03.2012 “Insurance After Death", Radikal, 13.03.2012 “More From the Shameful Tents".

Among the Second group the incident is reported indirectly and the main concern is to support the politicians, Sabah 29.03.2012 "INTES Draw Attention to Work Accidents"- news on the campaign organized by Organization of Construction Company Employers is given in an advertisement fashion. İstanbul Son Saat 17.03.2012 “Construction Sites are Supervised”. İstanbul Kent Yaşam 19.03.2012 "We Shall Take Lessons from this Disasters”. Ankara Gündem 13.03.2012 "Investigation Started for the Fire in Istanbul: Minister of Labor started investigation with his team". Among the third category the news are just summarizing the course of the events such as Hürriyet 15.03.2012 "6 Detention to 11 Lives".

TV news and videos can be divided into two groups, the news predominantly broadcasted on the following 5 days of the fire focusing on the heart-breaking stories of the workers, the causes of the fire, funerals, arrests of the responsibles and statements of the politicians. The news on the mainstream national TV broadcasts focus on the incident during the following five days between 12.03.2012-16.03.2012, however the researchers did not encounter any news on the trial process on the mainstream national broadcast. As for the time allocated for the news on tent fire, six TV Channels namely Show, NTV, TV8, TRT1, Star and Kanal 7 broadcasted news between 10-13 minutes throughout the five days. Six TV Channels broadcast duration is between 5-10 minutes, Kanaltürk, Ahaber, TGRT, TRT Haber, TRT Türk, Atv. Six of the channels gave less than 5 minutes on the incident. When considering there are 195 national broadcast channels the number of news and the channels that carry the tragedy to their broadcast is highly limited. One explanation for the limited number can be considered as some of the TV channels donot keep archives online open to the general access. It should not be cast aside that the data are only limited to those that the researchers reached online four years after the fire and maynot encompass all the news that were broadcasted back then.

The second group of videos are on the trial process and the demonstrations of the workers' families with civil initiatives predominantly broadcasted on social media by anonymous sources and local broadcasts. These videos, which are mostly anonymous, show the demonstrations and declerations of the workers' family members and lawyers after the trials. 
Finally few TV discussion shows mostly from the local and low rating broadcast discussing the policies economic structure and the legal process that victimizes the workers and their families.

Trt Türk on 13.03.2012 presents the news with these words "the electric stoves caused the fire that took 11 lives... after the fire Ankara took action and Faruk Çelik the Minister of Labour investigated the scene." The news continues to give space to minister's statements that "here there will not be any discrimination between the main employer and subcontractor, they are both responsibles and will be punished. The families of the deceased will be compensated". However the same channels that give such declerations of politicians donot report the trial process and how the "main responsibles" are not punished. Furthermore as the families of the victims declare they did not receive any compensation that would relieve their pain. Trt Haber on the same day makes news on the investigation that started and the authorities were at the fire scene, tragic stories of the workers, stories of poverty, deprivation and how they are compelled to leave their hometowns and work in the constructions in Istanbul. However the news are given as "the workers from different parts of Turkey after their bread shared the same tragedy" wihtout mentioning the underlying reasons for driving people from their homelands and desperately accepting the adverse conditions. In general the news present poverty and despair as sui generis.

Trt1 on 13.03.2012 report the incident by mentioning that electrical contact from the heating stoves caused the fire not questioning the non-existence of proper heating systems the news is presented as if it was a natural disaster. On the other hand TV8 on 13.03.2012 points to the neglect that caused the accident. All the news point to the fact that there is neglect and improper infrastructure for the accommodation of workers. However a construction of a millions of dollars worth shopping mall, hundreds of workers are accommodated, numerous warnings came from both the experts and workers about fire risk but not any of inspectors from the Ministry controlled and enforced provision for necessary conditions. The news while reporting the reactions of the politicians about the fire excludes such questions.

TV 8, TGRT, Kanal 7, Kanal D, TRT Türk, TRT Haber, CNN Türk 14.03.2012 "Farewell to the Victims" using dramatical voice and poetic expressions the news reporter is focusing on the pain of the families using terms like "tents becoming fireball" "the workers were behind 
their bread" "they couldn't escape hell" "the bodies beyond recognitions". The reports mention that the workers came from different parts of Turkey and their funerals are sent to their hometowns. All the reports also gives the brief stories of the deceased workers and reactions of their families. Kanal D and Kanal Türk stresses out the food and beverage delivery of Istanbul Metropolitan Municipality to the waiting families at the Institute of Forensic Sciences. TRT Türk and Kanal 7 also present Prime Minister's remarks on the fire stating that "We cannot accept those who make profits of billions of dollars to neglect and devalue the lives of labourers. Those who are responsible for this fire will be taken to the court as soon as possible". CNN Türk emphasises that in every construction in Istanbul, scenes of tents are common. Also the news indirectly takes the responsibility from the local governments by stating the words of Istanbul Metropolitan Mayor "we don't have regulations for the accommodation of workers at the construction sites so there are no standards." Forgetting the fact that condition detrimental to human life shall not need regulations but consciouscience of the administrators.

Show TV news on 15.03.2012 Ali K1rca, "Shocking Document" the journalist reports from the burned tents, showing the conditions, the electric heating system and other electric cables that caused the fire, the tents and its inflammable material, the only one entrance to the tents that caused the escape to be impossible. The documents presented in the news state how the workplace safety specialists warned the company 5 times about the unsafe electric ware in the tents.

In between lines Atv mentions on 16.03.2012 that the workplace safety specialist who has warned the company several times was also among the arrested. The safety coordinator in his defense states that he presented a report on the fatal risks at the workplace but the report was not taken seriously by the administration. According to Bugün and Kanaltürk's news on 16.03.2012 after the security inspection on 4 October 2011, the inspectors from the Ministry of Labor gave no risk report for the construction site without giving any space to the accommodation conditions of the workers in their report (http://beyazgazete.com/video/anahaber/kanalturk-32/2012/3/16/cadir-faciasina-6-tutuklama256092.html; http://beyazgazete.com/video/anahaber/bugun-tv-9/2012/3/16/cadir-faciasina-6tutuklama-256072.html; http://bianet.org/bianet/toplum/139688-esenyurt-yangini-davasi-ndaihmaller-ortaya-cikti, accessed on 19.05.2016). However according to the documents 
presented on Showhaber news report the workplace security specialists have been warning about the serious risk of fire since May 2011, in their reports all the risk factors are documented and photographed and shared with the administration. From the incident, the irrelevance of the discourses of the politicians' and the employers with the reality become clear. Establishment of councils, employment of consultants and specialists can be considered as only formality when their warnings are not taken into account. Furthermore, the inspection at the state level ignores the detrimental conditions for accommodation before the fire and did not enforce the required measures to be taken. The statements of the politicians afterwards the disaster is devoid of their sincerity when the factors leading to the disaster are considered. The political authorities with its insititutions share the responsibility of the fire with their insufficient and incapable auditing mechanisms. However in the statements of Ministers and mayors, all the blame is put on the employers while concealing their role in the incident. Furthermore even though the political authorities point to the employers, after three year trial period none of the employers as pointed by the politicians got any penalty. Stressing out Minister's statement that "no discrimination will be made between the subcontractor and main employers" after the court decision, only the employees of the subcontractor are sentenced to prison.

The news which are political by nature are instrumental not only in shaping the public opinion but also in suppressing the oppositional voices. The words chosen for news headlines function for making impression (Korkmaz ve Yaylagül, 2007:304). According to the critical approach, which criticises the liberal approach defining news as "objective", "non-biased", asserts that, those who claim the economic and political power determine the content and structure of the news, and shape how to think about certain issues. The critical approach reinforces the reproduction of social reality according to the hegemonic classes (Koç, 2012: 189). As an integral tool of political and economic production of social structure media facilitate within the rules of material production. Hence in Turkey media is dependend on political powers within its economic relations. Therefore, the news that construct meaning for the social space are devoid of a content that critcise and question the power relations. From the general frame of economy news, it becomes obvious that the media excludes a pluralist, egalitarian understanding that focuses on social and economic rights but the media blends in neoliberal ideology (Şen \& Avşar, 2012: 43). For instance especially in the mass media with higher circulation rates, the news donot mention the capital politics relationship behind the incident. 
The standing of the state is quite significant during the trial process by protecting the main responsibles however the media overshadows the power relations by emphasising the fire, tragic deaths, the poverty of the workers without revealing the real causes. In the previously stated videos, the perception management applied by the mainstream media becomes clear in their formulation of sentences in passive forms, focusing on fire, poverty and deprivation and ruling out the main reasons and socio-economic structure behind the fire, poverty and deprivation, giving space to the political authorities statements on how the responsibles will be punished but not giving any detailed information about the course of the trials and the court decision.

How the news be reported can be at journalist's disposal however, the process as Potter (2005) points out under the enforcement of the media owner who look after power relations (Aydın, 2015, 271). Which news to be presented is determined by journalists, editors and the owner and they all have different motives although, the power and capital owners filter and censor the news and provide government and interest groups to convey their message to public (Bly, 2002: 6-8). For instance, Kanal A, First Visuals From The Fire called news video, during the interview with the Mayor of Esenyurt, he says "the municipality doesn't have any responsibility for the fire, staying in the tents is not a problem". Savaş Ay an experienced journalist recorded the fire on his cellphone and showing to the cameras the workers who caught fire with the words "horrifying". Additionally Savaş Ay asks "you mentioned that they locked up other workers." And the witness responds as "yes they locked other workers to kitchen" and he continues his response but the channel cuts his answers and jumps to other displays from the fire. In this video, sensational visual displays and words that would attract the audience are picked but the attitude of the employers such as locking the workers and their neglect are cut off from the news. NTV news channel on 12 March 2012 broadcast the news on the fire with these statements: "Workers were staying in the tents. Because of the weather conditions, numbers of electrical stoves were used." "The first explanations of the authorities." "Investigation continues." "The tents used by workers for accomodation turned into ashes in seconds. In a construction site, at the tents where workers work." So NTV doesnot mention the name of the companies, Shopping mall construction site, the fact that it was not workers' choice to stay in the tents, focusing on the measures taken by authorities rather than the real causes of the fire. The news are constructed by focusing and 
attracting the attention to the poverty and inhumane conditions taking from its structural context and presenting the conditions sui generis.

Schiller mentions (1981) there is no free mobility of information but the existence of controllers auditors who are reshaping information (Siddiqui, 1990: 91). It is also important to question the social responsibility of the media due to the fact that the mass media rarely report the rights violations and donot give space to the representation of subaltern groups such as the poor, unpriviledged women and children (Şen ve Avşar, 2012: 43). Ideological standing is highly effective in the construction of the news content such as the news titles, visuals, sentence structure present clues for the viewpoints. The presentation of same events with varying contents reveals the cultural capital and ideological background (Özkır ve Şişman, 2014: 67). For instance Esenyurt Mayor declares on 12.03.2012 that "we cannot ask those who died how they died. 35 people can stay in a tent 50 people can stay in a tent. It is obvious that cold weather caused the fire. Their time came to an end, may god rest their soul." These statements were found its place in few web pages and in one discussion programme on Kanaltürk withouth mentioning the statements belong to the mayorl of the district. In other words the news reporters were obliged to conceal the owner of these insensitive statements for political concerns. However when it comes to how the food and beverage is served to the victims' families and the statements of politicians to the tragedy the news reporters do not hesitate to give the names of the authorities. Furthermore, the researchers did not encounter the above mentioned insensitive statement in any of the other mainstream channels (http://yerelgaste.com/IlceHaber.aspx?gn=934;

https://www.youtube.com/watch?v=GtP6K0dmTaw accesed on 18.05.2016).

The incidents in social life as in the case of workplace accidents' reflections on the media are shaped by the political powers and different interest groups' influence. As seen in the videos of the trial process, the real responsibles of the fire were able to escape the jurisdiction process and this was not reflected on the mainstream media. Therefore the researchers followed the course of the trials that led to the deliberation of the employers from the responsibility of the tragedy from videos shared by different platforms online. Quoting from a family member of one of the victims, "The main responsibles were protected, Ece Group, Kayı Construction and the auditors in the first expertise report. Their responsibilities were not mentioned. So we objected the first report, the second expertise report was even worse, blaming the victims and protecting the main responsibles. We again objected the report but 
unfortunately out objection was denied by the court. The court is postponed to 29 January 2015" (From Esenyurt Tent Fire Trials 34. Consciousness and Justice Watch https://www.youtube.com/watch?v=iYjOCeBucEM accessed on 18.05.2016). The fact that the controversial court decisions did not find enough space in the main stream news can be considered as the clues for the different interest groups' influence and impact on the media.

State with all its ideological and administrative instruments reproduce and legitimize the predetermined concepts. Especially mainstream media have an important mission in normalization of the language and the messages without questioning. The approach of mainstream media towards the incidents that reach beyond the accident level and be evaluated as murders, is the conscious discourse of mainstream/dominant/neoliberal economy politics that the media follows sui generis. Furthermore, the dominant neoliberal economy-political discourse hesitates using the term "work accident", and with so called solution oriented approach and disinformation attract the attention to "workplace health and security" (Taşbaş1, Yazıcı, Dağlı ve Özonur, 2014: 165). Similar to use of work accident, in the analysis of the news the researchers encountered the notion of "neglect" several times. For instance, Kanal 7 on 13 March 2012 broadcast the news entitled "Tent Turned into Ashes in 5 Minutes" directly quoting from the news reporter "the workers burned alive, their friends run to the screams of their friends, all happened in few minutes" from the voices of the survivor workers, the attention is directed to the causes mentioned as "negligence". According to the news the workers who teared down the tent to escape the fire caught in the electric wires surrounding the tents. The term neglect in this case is important for the fact that hiding the main motive of the employers for choosing the tents as accommodation. The unsafe electric wires, the use of electric stoves for heating, the insufficient conditions, the violation of safety regulations cannot be explained barely by neglect. Similarly, Beyaz TV on 14 March 2012 during the news broadcast entitled "Died Because of 3000 Turkish Liras" point out the fact that because it was 3000 Turkish Lira cheaper than the better equipped barracks, the inflammable tents were chosen: "The containers cost 5000 liras and the tents cost 2000 liras, the 3000 took the lives of the workers". The news is only for 1 minute, without mentioning any responsibles by using passive sentences, during the report the cheapness of workers' lives was stressed out by foreshadowing the motive of the employers in preferring cheaper materials for accomodation. Furthermore the researchers did not encounter the same news in other tv channels. 
In contrast to mainstream media, alternative media attempts to construct a counter argument with critical economic political discourse (Taşbaşı, Yazıcı, Dağlı ve Özonur, 2014: 166). As examples of the alternative media that continues to follow the trial process as well, local tv broadcasts and social media broadcasts can be put forward. On a Local TV broadcast, in a discussion programme, the wife of one of the deceased workers talk about the trial process, mentioning that it has been the $12^{\text {th }}$ trial but still no arrests. Quoting from her, "with each trial our sorrow deepens. It was obvious that the accident would occur, the workplace safety council has mentioned in their seven different report that the tents were not suitable and carry the danger of fire. The owners of Ece and Kayı companies, the owners of the mall and the construction company are not around. The deceased workers are found to be at fault. At the expertise report for the last trial, the 11 workers were stated as faulty. The report says the workers staffed sponge beds at the entrance of the tent and caused their own death. The workers are at fault at second degree." Again quoting from the wife "the employer says this is for you to stay. And they (the workers) need their bread, money they have to obey. If the worker resist to the conditions, they say take it or leave it. When they ask to the employers which tents shall we use their response was whichever is cheaper. The owners of the construction company are not found not coming to the trials and not facing the victims." (https://www.youtube.com/watch?v=Ax-tfljurkg, accessed on 03.05.2016).

Furthermore anonymous videos published on youtube, give voice to lawyers and family members of the workers who claim the main responsibles, the employers as murderers and are free. They feel violated when the employers offered money in order not to complain the court. To give examples; the civil initiative, Stop Worker Murders Platform, the representative says that "we don't want to see the ministers and prime minister only at the openings of these big centers and shopping malls, but also we want to see them at the trial courts and demonstrations of the workers who lost their lives at the constructions of these big centers and malls. They came and show off at the openings, ground-breaking ceremonies at the grand openings but neglect the workers it is the workers by which all these huge buildings as symbols of the economic growth that they are proud of rise. Everyday 5 workers die, here 11 workers died and so these buildings rise and the economy grows." (https://www.youtube.com/watch?v=IXtMfKIFS90). "57 years for 11 Lives" entitled video broadcasted on social media on 9 july 2015 presents lawyers' response to the decision of Bakıköy Heavy Penal Court. The lawyer representing the families' of the victims mentions 
that the real responsibles were not trialed and punished and the decision is far from establishing justice (https://www.youtube.com/watch?v=oytHXm35y_k).

From the analysis of the news videos it can be asserted that the mainstream national broadcasts news are limited to the three days following the incident, detailing the sorrow, deprivation and despair of the workers and the horror of the fire. The emphasis on the main causes and the power relations of capital that led to the detrimental conditions behind the fire are not revealed during the reports furthermore, the trial process the statements of the lawyers and families couldnot find place in the mainstream media. Another striking point is that in none of the news broadcasted by mainstream media, the name of the shopping mall, the name of the companies are mentioned. However in the anonymous videos broadcasted on social media the lawyers openly give the names of the shopping mall and the names of the main employers in their statements.

\section{Conclusion}

In the neo-liberal order, labor has gone through a restructuration process towards flexibility and a new organizational structure emerged whereby production is fragmented both spatially and temporal. Production has moved to the Third World predominantly signified by cheap labor and lack of social rights, capitalists in these countries take the advantage of legal loopholes and informal economy maximize their profit by making use of cheap and insecure work conditions (Bilgin et al, 2015: 21). This tendency in the labor structure characterised by flexibility, subcontractor, outsourcing, temporary contracts and part-time jobs. This flexibility enables the capital owners to increase their profit margins by lighting themselves from the labor costs. Whereas workers and their labor are commodified and used as long as and as much as they are needed. The deregulation of labor market for the sake of flexible employment sstrategy, involves increase in the mortality rates at the workplaces and work related diseases. Fatal accidents and serious injuries mostly occur in labor intensive sectors. In order to use cheap labor and lower the labor costs, forcing workers to longer work hours, outsourcing, increase in mobility and temporariness of workers and constantly employing younger, uneducated, unqualified and inexperienced wrokers, not providing workers with sufficient training, increased deregulation of workplace, loosening of controls on employers who are able to escape their responsibility of providing secure and healthy conditions are the main reasons for the increase in mortality at the workplace. 
Workplace Health and Security Code of 6331, bring important regulations in providing and preventing workplace accidents and diseases. The law was designed according to the modern global standards to prevent the accidents from the beginning (Korkmaz ve Avsalli, 2012: 154). However the Code was passed on 30 June 2012, nine years after the Labor Code and three months after the fire. In other words, the Labor Code that passed in 2003 does not include any regulations for workplace safety and if there were legislation that would be strictly implemented than the tragic incident wouldnot have taken place.

On the other hand existence of legislation by itself is not sufficient for the solution of the problems. In practice, as seen in the case of the death of 11 construction workers, during the trial process, the social security specialists and councils do not have a sanction power. Despite numerous reports by the workplace security councils, the companies both the main employer and subcontractor did not take any steps to prevent the fire. Laws just on the paper cannot be considered sufficient when the mechanisms for proper implementation donot exist, when the judiciary power protects the main responsibles and put all the cost on the deceased and the victims. Acknowledging that there will not be any penalty for violation of the laws, the employers feel free to implement practices contrary to what the law states. The protecitionist attitude of the state and the government towards the main capitalist with its legislative mechanisms foreshadows the developments that remain only on the paper. Furthermore, the 4857 Code on Labor does not clarify the solutions for the workers and their families who are victims of workplace accidents. The Law doesnot bring any regulations in favour of the workers who are victims of work related disease and accidents and their families (Ekmekçioğlu, 2003: 77).

From the data analysis, the researchers encountered the hints of perception management strategies as reflected on the political discourses and on the news reports about the fire incident.Both the politicians and the journalists interpret the fire according to their political standings and also report to the audience accordingly. Politicians adopt perception management strategies in order to legitimize their practices in the eyes of the public. Similarly pro-government journalists' news about the fire are limited to the individual stories of the victims and the horror of the fire. Journalists with oppositional tendencies point to the government and government's interest relations with the capital as the main responsible of the 
fatal workplace accidents in general and the fire in particular. In oppositional newspapers question the general attitude of the government behind the fire.

The neo-liberal politics and its emphasis on competitive free market, the idea that capitalists shall be supported for the pursuit of profit maximization constitute the main framework for understanding the workplace accidents. Concomitantly, especially in the developing countries, neo-liberal politics are pursued at the cost of social welfare regulations, which also have devastating impacts in terms of work place safety. For preventing the fatal workplace accidents, necessary regulations shall be taken in order not to prioritize pro-capitalist neoliberal policies over humanitarian conditions. It is also important to raise social awareness for the prevention of fatal workplace accidents and to put pressure on capitalists as well as politicians. Therefore it is highly crucial for media to focus on the deep rooted concealed factors behind the accidents by distancing themselves from political concerns. 


\section{References}

Adalet Arayana Destek Grubu Kolektif (2016). Işs Cinayetleri Alamanăğ 2015, İstanbul: BirUmut

Appadurai, A. (2001). Grassroots Globalization and the Research Imagination. In A. Appadurai (ed.), Globalization (1-21). A Millenial Quartet.

Aydın, S. (2015). Türk basınında bir içerik analizi çalışması: Ermenek faciası haberleri. Ejournal of Intermedia, 2(1)

Bedirhanoğlu, P., Yalman, G. L. (2010). Reflections on the Neoliberal Transformation in Turkey. Economic Transitions to Neoliberalism in Middle-income Countries: Policy Dilemmas, economic crises, forms of resistance, A. Saad-Filho, G.L. Yalman (eds.), Routledge.

Bly, T. (2002). Impact of public perception on us national policy: A study of media influence in military and government decision making. Master Of Science In Information Systems And Operations Naval Postgraduate School

Brass, T. (2015) Free Markets, Unfree Labour: Old Questions Answered, New Answers Questioned, Journal of Contemporary Asia, 45:3, 531-540

Callamari, P.; Reveron, D. (2003). China's Use of Perception Management International Journal of Intelligence and CounterIntelligence, 16: 1-15

Chomsky, N., Herman,E. (1988). Manufacturing Consent. New York: Pantheon Books.

Dearth, D.H. (2002). Shaping the Information Space. Journal of Information Warfare. 1(3), 115

Ekmekçioğlu, H. (2003). 4857 Sayılı İş Kanunun Genel Değerlendirmesi, TBB Dergisi, 48: 73-77, Accessed from: http://tbbdergisi.barobirlik.org.tr/m2003-48-765 on 06.05.2016

Garfield, A. (2002). The Offence of Strategic Influence: Making the Case for Perception Management Operations. Journal of Information Warfare 1, 3, 32.

Gürsoy, Ö. B. (2010). Bir Yaşam Biçimi Olarak Dışlanma: Türkiye'de Mevsimlik Tarım İşçileri, Sınıftan Sınıfa, Türkiye'de Fabrika Dışında Çalışma Manzaraları A. Buğra (ed.), İletişim, İstanbul.

Harvey, D. (2005). A Brief History of Neoliberalism. Oxford University Press.

Hoşgör, E. (2015). The Question of AKP Hegemony: Consent without Consensus. The Neoliberal Landscape and the Rise of Islamist Capital in Turkey, N. Balkan, E. Balkan \& A. Öncü (eds.), Berghahn, Oxford. 
Ishay, M. (2004, December). Promoting Human Rights in the Era of Globalisation and Interventions: the Changing Spaces of Struggle. Globalizations 1(2), 181-193. Taylor and Francis Group.

Keane, J. (2003). Global Civil Society? Cambridge, England: Cambridge University Press.

Klein, N. (2002). No Logo, Nalan Uysal (Çev), Ankara:Bilgi.

Koç, N.K. (2012). Türkiye'deki Yazılı Basında Tekel İşçi Eyleminin Sunumu. Çalışma ve Toplum. 4 (35),189-215

Korkmaz, A.; Avsallı, H. (2012). Çalışma Hayatında Yeni Bir Dönem: 6331 Sayılı İş Sağlığı ve Güvenliği Yasası. SDÜ Fen Edebiyat Fakültesi Sosyal Bilimler Dergisi. 26 ( ),153167

Korkmaz, N.; Yaylagül, L.(2008). 2007 Y1lı 1 Mayıs Etkinliklerinin Türkiye'deki Yazılı Basında Sunumu, Almanak- 2007 Analizleri. İstanbul: Sosyal Araştırmalar Vakfı. 22, 296- 313.

Martemucci, M. G. (2007). Regaining the high ground: The challenges of perception management in national strategy and military operatıons. Faculty of the Joint Advanced War Fighting School, Master of Science Degree in Joint Campaign Planning and Strategy.

Mezzadri, A (2010). Neoliberalism, industrial restructuring and labour: lessons from the Delhi garment industry. Economic Transitions to Neoliberalism in Middle-income Countries: Policy Dilemmas, economic crises, forms of resistance, A. Saad-Filho, G.L. Yalman (eds.), Routledge.

Mütevellioğlu, N., Işık, S. (2009). Türkiye Emek Piyasasında Neoliberal Dönüşüm. Küreselleşme, Kriz ve Türkiye’de Neoliberal Dönüşüm. N. Mütevellioğlu, S. Sönmez (eds), İstanbul Bilgi Üniversitesi, İstanbul.

Özer, M.A. (2012). Bir modern yönetim tekniği olarak algılama yönetimi ve iç güvenlik hizmetleri

Özkır, Y.; Şişman, B. (2014). Soma Maden Kazasının İnternet Gazetelerinde Aktarılmasının Haberde İdeoloji Bağlamında Değerlendirilmesi. Iğdır Üniversitesi Sosyal Bilimler Dergisi. 6, 65-81

Öztürk, Ö. (2015). The Islamist Big Bourgeoisie of Turkey. The Neoliberal Landscape and the Rise of Islamist Capital in Turkey, N. Balkan, E. Balkan \& A. Öncü (eds.), Berghahn, Oxford.

Saydam, A. (2012). İletişimin Akı1 ve Gönül Penceresi: Alg1 yönetimi. İstanbul: Remzi 
Şen, F.; Avşar, Z. (2012). Türkiye'de neoliberal politikaların haber medyasına yansımaları: Anaakım medyanın ekonomi haberleri üzerine bir inceleme. İletişim Kuram ve Araştırma Dergisi - Sayı 35

Siddiqui, D. A. (1990). Book Review: Manifactoring constent: The political economy of mass media. The American Journal ofSocial Sciences. 7 (1),

Taşbaşı, K.; Yazıcı, G.; Dağlı, B., Özonur, D. (2014). Kaza Mı? Cinayet Mi? Gazete Haberlerinde İşçi Ölümleri. LaborComm 2014 Bildiriler Kitabı, 153-167

The US Department of Defense (2003). Dictionary of military and associated terms. Joint publication

Van Dijk, T. A. (1993). Principles of Critical Discourse Analysis. Discourse Society. 4, 249

http://beyazgazete.com/video/anahaber/kanal-7-28/2012/3/13/cadir-5-dakikada-kul-oldu255016.html

http://beyazgazete.com/video/anahaber/kanal-7-28/2012/3/14/esenyurt-taki-cadir-faciasi255507.html

http://beyazgazete.com/video/anahaber/trt-haber-67/2012/3/15/gozaltina-alinan-11-kisi-den6-si-tutuklandi-255648.html

http://eskiweb.tekstil.itu.edu.tr/DataFiles/Dosya/Tommy_Son\%20Saat.pdf accessed on: 13.05.2016

http://www.ensonhaber.com/resimler/diger/tirajx_8963.jpeg accessed on 13.05.2016

http://www.medyatava.com/tiraj accessed on 13.05.2016

http://www.ttso.org.tr/dosyalar/basinhaberleri/2015-agustos.pdf accessed on 13.05.2016

www.etimolojiturkce.com

www.etymonline.com/index.php?allowed_in_frame=0\&search $=$ perception\&searchmode=non $\mathrm{e}$

Yetkin, B. (2011). Haber söyleminde egemen ideolojinin yeniden üretimi: Magazinleşme bağlamında bir analiz. İletişim Kuram Ve Araştırma Dergisi, 33, 27-60 